\title{
THE RETURN OF COVERTURE
}

\author{
Allison Anna Tait ${ }^{*}$
}

Once, the notion that husbands and wives were equal partners in marriage seemed outlandish and unnatural. Today, the marriage narrative has been reversed and the prevailing attitude is that marriage has become an increasingly equitable institution. This is the story that Justice Kennedy told in Obergefell v. Hodges, in which he described marriage as an evolving institution that has adapted in response to social change such that discriminatory marriage rules no longer apply. Coverture exemplifies this change: marriage used to be deeply shaped by coverture rules and now it is not. While celebrating the demise of coverture, however, the substantive image of marriage that Justice Kennedy set forth subconsciously uses conventional, historical tropes that construct marriage as a relationship of hierarchy, gender differentiation, and female disempowerment. In this Essay, I describe the ways in which Justice Kennedy used coverture as a positive example of marriage transformation while simultaneously invoking coverture ideals to inform his portrayal of marriage as a fundamental building block of government, the keystone of civil society, and a transcendental, lifelong commitment.

Once, in the era of coverture, the notion that husbands and wives were equal partners in marriage seemed outlandish and unnatural. Under coverture, a married woman had no legal persona-she could not sue or be sued, she could not form contracts, and she could not buy, sell, or own property apart from her husband. ${ }^{1}$ Gender hierarchy, separate spheres, and marital "unity" defined coverture and its rules.

Today, the prevailing narrative is that marriage has become an increasingly equitable institution. This is the story that Justice Kennedy told

* Assistant Professor, University of Richmond School of Law. For comments and conversation, my thanks go to Claudia Haupt, Corinna Lain, Shari Motro, Luke Norris, Sarah Swan, and Mary Kelly Tate. I am also very appreciative for Erin Whelan's assistance and Andrew Xue's excellent editorial work.

1. AMY LOUISE ERICKSON, WOMEN AND Property IN EARLy MODERN ENGLAND 2425 (1993). All "moveables" or "chattels" - which included money, clothing, jewelry, furniture, and other personal goods-that previously belonged to the wife became the property of the husband, as did any leasehold land. Id. See also Allison Tait, The Beginning of the End of Coverture: A Reappraisal of the Married Woman's Separate Estate, 26 YALE J.L. \& FEMINISM 165, 167 (2014). But see J.H. BAKER, AN INTRODUCTION TO ENGLISH LEGAL HISTORY 483-84 (4th ed. 2002) ("Like most legal fictions [coverture] was not universally applicable: for instance, the wife was not executed for her husband's crimes, or made answerable for his debts.”). 
in Obergefell $v$. Hodges, in which he described marriage as an evolving institution that has adapted in response to social change. Coverture, for Justice Kennedy, exemplifies this change: marriage used to be deeply shaped by coverture rules and now it is not. Coverture therefore provides an important example of how "[t]he history of marriage is one of both continuity and change." 2

While celebrating the demise of coverture, however, the substantive image of marriage that Justice Kennedy set forth in the opinion subconsciously invokes marriage as coverture. The opinion uses conventional, historical tropes that construct marriage as a relationship of hierarchy, gender differentiation, and female disempowerment. While ostensibly rejecting old forms of marriage and setting forth a modern vision of marriage equality, the opinion subtly resurrects the presence of coverture.

Obergefell has already been the subject of critique-both from the dissenters on the court and from legal commentators-because of the florid language used in tribute to marriage ${ }^{3}$ as well as the dated picture of marriage that the opinion presents. ${ }^{4}$ These critiques do not, however, explore just how regressive Justice Kennedy's vision of marriage is. In this Essay, I describe the ways in which Justice Kennedy used coverture as an example of marriage transformation while simultaneously invoking coverture ideals to inform his portrayal of marriage as a building block of government, the keystone of civil society, and a transcendental, lifelong commitment.

2. Obergefell v. Hodges, 135 S. Ct. 2584, 2595 (2015).

3. Id. at 2628 (Scalia, J., dissenting) (describing the majority opinion prose as "mummeries and straining-to-be-memorable passages").

4. See, e.g., Michael Cobb, Opinion, The Supreme Court's Lonely Hearts Club, N.Y. TIMES (Jun. 30, 2015), http://www.nytimes.com/2015/06/30/opinion/the-supreme-courtslonely-hearts-club.html [perma.cc/N2U8-LK3K]; Claire Potter, Why People Who GayMarry Need Feminism, S-USISH (July 2, 2015), http://s-usih.org/2015/07/why-people-who-gaymarryneed-feminism.html [perma.cc/4YP9-DLAA]; see also Cynthia Godsoe, Marriage Equality and the "New" Maternalism, 6 CAL. L. REV. CIRCUIT 145, 147 ("The ongoing gendered stereotypes embedded in Obergefell limit marriage equality's egalitarian power, ultimately restricting options for all families"); Nan D. Hunter, Interpreting Liberty and Equality Through the Lens of Marriage, 6 CAL. L. REV. CIRCUIT 107, 108 ("I argue in this Essay that Obergefell elevates traditionalist concepts of marriage over principles of liberty or equality"); Clare Huntington, Obergefell's Conservatism: Reifying Familial Fronts, 84 FORDHAM L. REV. 23, 23 ("[The Court's framing] unnecessarily disrespects people who in good faith have a different view of the social front of marriage. And it reifies marriage as a key element in the social front of family, further marginalizing nonmarital families."); Serena Mayeri, Marriage (In)equality and the Historical Legacies of Feminism, 6 CAL. L. REV. CIRCUIT 126, 134 ("Obergefell does not bear the marks of feminism's second legacy-the campaigns against discrimination based on nonmarital status."). 


\section{THE LONG REIGN OF COVERTURE}

Sir William Blackstone, in a famous passage from the first volume of his 1765 Commentaries, described the doctrine of coverture as follows:

By marriage, the husband and wife are one person in law: that is, the very being or legal existence of the woman is suspended during the marriage, or at least is incorporated and consolidated into that of the husband: under whose wing, protection, and cover, she performs every thing; and is therefore called in our law-French a feme-covert. ... ${ }^{5}$

Justice Kennedy, citing this classic definition, reiterated: "Under the centuries-old doctrine of coverture, a married man and woman were treated by the State as a single, male-dominated legal entity." ${ }^{\text {The }}$ The rules governed married women in both England and America until at least the middle of the nineteenth century, when states began to enact Married Women's Property Acts, legislation that is generally thought to have ended coverture. ${ }^{7}$

Practical economic concerns led courts and legislatures to reconsider the rules of coverture because there were "advantages in treating spouses' assets separately: a wife's property could keep a family solvent if a husband's creditors claimed his assets, and employed married women could support their children if their husbands were profligate." ${ }^{8}$ Moreover, Justice Kennedy mentioned that new social understandings concerning women as legal and political rightsholders were gaining traction: "As women gained legal, political, and property rights, and as society began to understand that women have their own equal dignity, the law of coverture was abandoned."

Despite these motivating factors, coverture was not challenged or changed without great effort. Dismantling coverture, the historians' brief remarks, was a contentious undertaking that contravened what many people considered to be the natural order of marital relations. The project of changing coverture rules was portrayed as destroying a core feature of marriage: "To eliminate it was blasphemous and unnatural; the marriage bargain was governed by laws of 'Divine origin' and subordination was 'the

5. 1 William Blackstone, COMMENTARIES ${ }^{*} 442$.

6. Obergefell, $2584 \mathrm{~S}$. Ct. at 2595 (citing 1 BLACKSTONE supra note 5 , at ${ }^{\star} 430$ ).

7. See Tait, supra note 1 , at $212-24$. While married women gained property rights pursuant to these statutes, many coverture rules remained in place until late into the twentieth century, such as head of household rules. See Allison Anna Tait, A Tale of Three Families: Historical Households, Earned Belonging, and Natural Connections, 63 HASTINGS L.J. 1345, 1355 (2012).

8. Brief of Historians of Marriage and the American Historical Ass'n as Amici Curiae in Support of Petitioners at 17, Obergefell, 135 S. Ct. 2584 (Nos. 14-556, 14-562, 14-571 and 14574) [hereinafter Brief of Historians of Marriage].

9. Obergefell, 2584 S. Ct. at 2595. 
price which female wants and weakness must pay for their protection.' "10 Many people considered coverture to be an essential component of the marriage relationship, and its rules shaped social expectations as well as cultural representations of marriage. ${ }^{11}$

\section{COVERTURE'S RESURRECTION}

The Married Women's Property Acts and other legal changes did gradually eradicate the most obvious facets of coverture. Women became property owners, legal actors, and economic deciders. Women came one step closer to being equal partners in the marital relationship. Justice Kennedy therefore wrote that the ultimate legal rejection of coverture brought about by the Married Women's Property Acts "worked deep transformations in its structure, affecting aspects of marriage long viewed by many as essential." 12

Nevertheless, at the same time that Justice Kennedy described marriage as an "institution [that] has evolved in substantial ways over time, superseding rules related to parental consent, gender, and race once thought by many to be essential," ${ }^{13}$ he also reaffirmed certain tenets of coverture. He wrote that, "[m]arriage remains a building block of our national community," 14 and used metaphors and descriptors that have particular rhetorical pedigrees. Describing marriage as a building block of government, the keystone of social order, and a transcendent, lifelong relationship, Justice Kennedy invoked longstanding tropes that have traditionally been deployed in defense of coverture and marriage defined by gender inequality. ${ }^{15}$

10. Brief of Historians of Marriage, supra note 8, at 18 (citing BASCH, IN THE EYES OF THE LAW 154 (1999)).

11. Chief Justice Roberts disputed this historical characterization of the importance of coverture to marriage by stating: "If you had asked a person on the street how marriage was defined, no one would ever have said, 'Marriage is the union of a man and a woman, where the woman is subject to coverture. ' Obergefell, 2584 S. Ct. at 2614 (Roberts, C.J., dissenting).

12. Obergefell, 2584 S. Ct. at 2595 (citing NANCY COTT, PUBliC Vows (2000); HENDRIK HARTOG, MAN \& WIFE IN AMERICA: A HisTORY (2000)).

13. Id. at 2601 .

14. Id. See generally COTT supra, note 12 .

15. See Mary Lyndon Shanley, Marriage Contract and Social Contract in Seventeenth Century English Political Thought, 32 W. POL. Q. 79, 79 (1979) ("The royalists thought they had found in the marriage contract a perfect analogue to any supposed contract between the king and his subjects, for marriage was a contract but was in its essence both hierarchical and irrevocable.... [Parliamentarian and republican writers] gradually extended their individualistic premises into the depiction of domestic order."). 


\section{A. Marriage as the Building Block of Government}

One of the first statements that Justice Kennedy made about marriage is that it "lies at the foundation of government." ${ }^{16}$ Justice Kennedy attributed this maxim to Confucius and stated that it was "echoed centuries later and half a world away by Cicero, who wrote: 'The first bond of society is marriage; next, children; and then the family.' " 17 The tie between family and government has, as Justice Kennedy observed, been an essential one.

The tie between the family and government has also historically been premised on cascading forms of paternal authority and entrenched gender hierarchy. ${ }^{18}$ Early modern political theorists, like Jean Bodin, framed governmental structure in terms of the family: "The family [is] not only the true source and origin of the commonwealth, but also its principal constituent." 19 The family held great significance because its structure both confirmed and reinforced the correctness of authoritarian or monarchical rule. ${ }^{20}$ Here, political theorists drew on Aristotle, who posited the family as the template of government: "For as household management is the kingly rule of a house, so kingly rule is the household management of a city, or of a nation, or of many nations." ${ }^{21}$ This use of the family as an exemplary organizational form culminated in England with Robert Filmer who in 1680 wrote Patriarcha, or the Natural Power of Kings. In that book, Filmer stated: "If we compare the Natural Rights of a Father with those of a King, we find them all one... as the Father over one Family, so the King as Father over many Families extends his care to preserve, feed, cloth, instruct, and defend the whole Commonwealth." 22

This tight connection between polity and family was reconceived in American political theory and the central component of the governmental analogy shifted from nesting forms of domestic and political power to a

16. Obergefell, 2584 S. Ct. at 2594 (citing 2 LI CHI: BOOK OF Rites 266 (Ch'u Chai \& Winberg Chai eds., James Legge trans., 1967)).

17. Id. (quoting CICERO, DE OfFICIIS (Walter Miller trans., 1913)).

18. See Allison Tait, Family Model and Mystical Body: Witnessing Gender Through Political Metaphor in the Early Modern Nation-State, 36 WOMEN's STUD. Q. 76, 78 (2008) (“In the absolutist context, the family unit (in its most conventional makeup) is the primary expression of political organization.").

19. JeAn Bodin, Six Books of The Commonwealth 6 (M. J. Tooley trans., 1967).

20. See JONATHAN DEWALD, ARISTOCRATIC EXPERIENCE AND THE ORIGINS OF MODERN CUlture 78 (1993) ("From Bodin in the sixteenth century through Montesquieu in the eighteenth, theorists argued that the authority of the polity rested on properly functioning families, and above all on proper respect for fathers. Order in the small, familial polity would lead to order in the polity at large and to respect for its father, the king." (footnote omitted)).

21. Aristotle, Nichomachean Ethics, in InTROdUCtion to ARISTOTLE, 609 (Richard McKeon ed., 1947).

22. ROBERT FILMER, PATRIARCHA 24 (1680). 
robust idea of consent: "[A]s a voluntary union based on consent, marriage paralleled the new government. This thinking propelled the analogy between the two forms of consensual union into the republican nation's selfunderstanding and identity." ${ }^{23}$ Despite this new emphasis, consent-based concepts of marriage still retained internal, gendered hierarches. Women may have been consenting to marriage, as opposed to being co-opted into marital arrangements for purposes of wealth creation or family convenience, but these women were nonetheless consenting to a legal relationshipcoverture-in which they had few rights and were ruled by their husbands. Fathers and husbands in America were "enlightened patriarchs"; that is to say, they were not tyrants but rather heads of household who exercised their authority with compassion and wisdom. ${ }^{24}$ They were, however, still patriarchs and, even in America, the idea of marriage as a building block of government was connected to female subordination and coverture rules.

\section{B. Marriage as Key to Social Order}

Another point that Justice Kennedy made in favor of marriage as a fundamental right is that "this Court's cases and the Nation's traditions make clear that marriage is a keystone of our social order." ${ }^{25}$ Quoting from Maynard v. Hill-a case from 1888 that turned not on the question of marriage but rather on questions of legislative divorce and marital property-Justice Kennedy asserted that marriage "has long been 'a great public institution, giving character to our whole civil polity." "26 Because of the importance of the family as a unit of governance, commentators have conventionally and regularly deemed the family to be a "keystone of our social order." In early modern England, Blackstone observed that "the due regulation and domestic order of the kingdom" was connected to the proper functioning of "a well-governed family." 27 Alice Kessler-Harris has noted likewise that this notion of family as "a keystone of social order" 28 resonated strongly in Puritan New England and that, by the middle of the nineteenth

23. COTT, supra note 12 , at 10.

24. See, e.g., GORDON S. WOOD, THE RADICALISM OF THE AMERICAN REVOLUTION 146 (1991) (describing "new enlightened standards of paternalism").

25. Obergefell v. Hodges, 135 S. Ct. 2584, 2601 (2015).

26. Id. (quoting Maynard v. Hill, 125 U.S. 190, 213 (1888)).

27. 4 BLACKSTONE, supra note 5 , at ${ }^{\star} 162$.

28. Alice Kessler-Harris, Women, Work, and the Social Order, in LIBERATING WOMEN's History: THEORETICAL AND CRITICAL ESSAYs 330, 331 (Berenice A. Carroll ed., 1976). 
century, the family was "understood as the basic social unit, essential to social order." 29

The real question, however, remains unanswered. That is, which social order does marriage support? One answer to this question comes from Alexis de Tocqueville, who Justice Kennedy quoted: "[W]hen the American retires from the turmoil of public life to the bosom of his family, he finds in it the image of order and of peace... [H]e afterwards carries [that image] with him into public affairs." ${ }^{30}$ If this quote is any indication, the social order that marriage supports consists of two clearly delineated and separate spheres that partition men and women into the dichotomous roles of female domesticity and male wage-earning. This vision of marriage is one in which a husband braves the "turmoil" of public life and marketplace engagement in order to be rewarded at the end of the day with a peaceful home that is ordered and run by his wife.

This ideal social order is constituted by specialized labor and genderdifferentiated roles. A feature of coverture, specialized household labor became entrenched at the end of the nineteenth century when "wives' economic contribution to the household was no longer as 'visible" as it had been in the more subsistence-oriented agrarian economies," and "[g]rowing numbers of men had begun to work outside the household." ${ }^{31}$ Because of these changes in the social and industrial landscape, household labor "increasingly appeared an indistinguishable part of 'family life.' "32 Men worked in the paid labor market, striving for financial success, while women were to prepare themselves for "a great calling" ${ }^{3}$ - motherhood. Homemaking, mothering, and domestic arts "reached mystical proportions" and "[f] or a woman to neglect her duty meant social chaos." 34 Motherhood frames this social order and its absence indicates social chaos.

A second answer to the question of which social order marriage supports emerges when Justice Kennedy remarked that, without marriage, "there would be neither civilization nor progress." ${ }^{35}$ The concept of "civilization"-like the concept of separate spheres-reinforces particular types of social ordering and requires certain forms of marital behavior.

29. Id. at 332

30. Obergefell, $135 \mathrm{~S}$. Ct. at 2601 (alteration and omission in original) (quoting 1 ALEXIS DE TOCQUEVIlle, DEMOCRACY IN AMERICA 309 (Henry Reeve trans., rev. ed. 1990)).

31. Reva B. Siegel, Home as Work: The First Woman's Rights Claims Concerning Wives' Household Labor, 1850-1880, 103 YALE L.J. 1073, 1092 (1994).

32. Id.

33. Kessler-Harris, supra note 30, at 332.

34. Id. Nancy Cott, discussing marriage in America at the turn of the nineteenth century, likewise notes that "social order [was] based on male-headed nuclear families." COTT, supra note 12 , at 92 .

35. Obergefell, 135 S. Ct. at 2601 (quoting Maynard v. Hill, 125 U.S. 190, 211 (1888)). 
Norbert Elias writes: “The term 'civilization' sums up everything in which Western society of the last two or three centuries believes itself superior to earlier societies.... By this term Western society seeks to describe what constitutes its special character and what it is proud of." 36 "Civilization" is, accordingly, intimately linked to the perpetual refinement of elite and oftenconservative norms. In the context of marriage and sexuality, "civilization" means that "sexuality is confined more and more exclusively ... [to] socially legitimatized marriage" ${ }^{37}$ as individuals are called upon to exercise selfrestraint and discipline internal drives.

Correct social ordering in the marriage realm meant keeping up appearances and following the "rules of propriety, good neighbourhood, and good manners." ${ }^{38}$ By the mid-nineteenth century the civilizing process required "a particularly strict disciplining of sexuality" and the total integration of "social commands and prohibitions" into all modes of household management and marital relations. ${ }^{39}$ Katherine Franke has shown, from this perspective, how marriage has been used by the American government as a "domesticating technology" capable of "lift[ing] people up from a natural savage state and mold[ing] them into proper citizens," 40 in particular after the Civil War and the freeing of the slaves. Accordingly, the rules of civility, like the rules of specialized labor, provide an apparatus for conforming marital relations, gender roles, and sexual behavior to collective sociocultural norms.

\section{Marriage as a Transcendental, Lifelong Relationship}

A third element that characterizes Justice Kennedy's description of marriage as coverture is his insistence on marriage as a lifelong, transcendental undertaking. Justice Kennedy wrote: "The lifelong union of a man and a woman always has promised nobility and dignity to all persons, without regard to their station in life." ${ }^{41}$ And in a similar vein, he also asserted that marriage "offers the hope of companionship and understanding and assurance that while both still live there will be someone to care for the

36. Norbert Elias, The Civilizing Process: Sociogenetic and Psychogenetic INVESTIGATIONS 5 (Edmund Jephcott trans., 1994).

37. Id. at 188 .

38. 4 BLACKSTONE, supra note 5 , at ${ }^{*} 162$.

39. Id. at 186. Elias describes bourgeois society and its norms in nineteenth-century Europe in comparison with the previous court society that dominated in Ancient Regime France and elsewhere in Europe.

40. Katherine M. Franke, Becoming a Citizen: Reconstruction Era Regulation of African American Marriages, 11 YALE J.L. \& HuMAN. 251, 252 (1999).

41. Obergefell v. Hodges, 135 S. Ct. 2584, 2594 (2015) (emphasis added). 
other." 42 To be sure, few couples enter into marriage with the idea of getting divorced, and this description of marriage therefore reflects a common, aspirational vision of the relationship. But, from a different perspective, the description of marriage as a lifelong relationship harkens back to an era before the availability of divorce - the era of coverture-when marriage was literally a lifelong proposition defined by the near impossibility of exit.

Until the middle- to late-nineteenth century, both in England and America, the lack of real exit opportunities was a defining feature of marriage. Grounded in religious theory and the idea of "one flesh," 43 the model marriage fit a particular paradigm: "lifelong, faithful monogamy, formed by the mutual consent of a man and a woman." ${ }^{44}$ Lifelong marriage also dovetailed with the concept of coverture, in which a woman became unalterably one with her husband at the moment of marriage. Coverture "literally expressed the union of the marital pair" and the dictum "till death do us part," was as central a component of coverture as was the unity of property or political interests of the married couple. ${ }^{45}$

Under coverture rules, there was no real escape for a wife even in cases of abuse, unhappiness, or incompatibility. In England, the only way to obtain a full divorce (with permission to remarry) was to obtain an Act of Parliament. Generally, men obtained a private Act when they were able to prove adultery and had sufficient resources to navigate the time- and expense-consuming process. ${ }^{46}$ The more common solution was for the spouses to obtain a divorce $a$ mensa et thoro from the ecclesiastical court. This was a legal separation that allowed the spouses to live apart and even granted alimony to the wives under certain circumstances. ${ }^{47}$ It was not until 1857, with the Matrimonial Causes Act, that divorce became more readily available and, even then, the social stigma attached to divorce was often prohibitive. $^{48}$

In American colonies and states, divorce availability varied by geography. ${ }^{49}$ Full divorce was available relatively early in some New England

42. Id. at 2600 (emphasis added).

43. E.g., СоTT, supra note 12, at 11, 66 .

44. Id. at 3. See also Norma Basch, Invisible Women: The Legal Fiction of Marital Unity in Nineteenth-Century America, 5 FeMINIST STUdIES 346, 354 (1979).

45. CоTT, supra note 12, at 54.

46. Tait, supra note 1, at 184.

47. Id. at $184-85$.

48. Matrimonial Causes Act 1857, 20 \& 21 Vict., c. 85, (Eng.); Tait, supra note 1, at 184.

49. See Marylynn Salmon, Women and the LaW of Property in Early America (1989). 
states, perhaps because of "reformation roots." 50 Nevertheless, access to divorce was both rarely found and rarely employed until the middle of the nineteenth century. Even once divorce became more common, spouses had to show fault (a requirement that persisted into the 1970s and 1980s in most states), meaning that women still did not have guaranteed exit from an unhappy or even abusive marriage.

Consequently, no one knew better that "[c]hoices about marriage shape an individual's destiny" ${ }^{51}$ than a woman stuck in a lifelong marriage to a philandering, abusive, or spendthrift husband. Marriage was lifelong and unifying in the context of coverture, and it was both of these things at the expense of female identity, agency, and even bodily integrity. Accordingly, the idea of lifelong marriage, while aspirational, is also tied to a historical notion of marriage defined by coverture, interest unification, and the suppression of female agency.

To be sure, none of these tropes are, nor have they ever been, static. They can and have evolved to fit multiple circumstances and cultural contexts. Nevertheless, they have primarily been used in the service of defending forms of marriage that trade heavily in conventional social ordering, specialization of labor, and power asymmetries premised on gender differences. Justice Kennedy's opinion adopted these tropes without acknowledging their historical freight, glosses over how we might construct or reconstruct them, and invokes them as universal truths rather than politicized assertions.

\section{CONCLUSION}

With the decision in Obergefell, not only did the notion of love win, the institution of marriage also won. ${ }^{52}$ And through it all, a particularly conventional iteration of marriage predominated. In Kennedy's idealistic and idealizing concept of marriage, the relationship is important because it models good governance, social stability, and enduring commitment. The descriptive language that he used, however, invokes not only good governance but also gender hierarchy; not only social stability but also social prescription; not only enduring commitment but also inescapable burden. Consequently, instead of extinguishing dated concepts about the nature of

50. Judith Areen, Uncovering the Reformation Roots of American Marriage and Divorce Law, 26 YALE J.L. \& FEMINISM 29 (2014).

51. Obergefell v. Hodges, 135 S. Ct. 2584, 2599 (2015).

52. Katherine Franke responds to the victory of marriage equality by posing this question: "Given that hundreds of thousands of same-sex couples have legally married, now is the time to ask this important, if not painful, question: What have we gotten ourselves into?" KATHERINe Franke, Wedlocked: THE PERILS OF MARRIAGE EQUALITY 209 (2015). 
marriage and replacing them with a more modern form of marriage, grounded in true gender equality and relationship equity, Obergefell signals a new life for coverture values. As the French might say, coverture is dead; long live coverture. 
